\title{
Reduction of Pollutant Emission in Ethanol-Gasoline Blends Engines with Magnetic Fuel Conditioning
}

\author{
Ra'ad A. Khalil \\ University of Mosul, College of engineering, Mechanical Engineering Department, Mosul.
}

\begin{abstract}
This paper represents an experimental investigation to evaluate the effect of magnetic field on exhaust emissions and engine performance of four-stroke, single piston spark-ignition engine working with $(10 \%$ vol.)Ethanol-Gasoline blends. Carbon monoxide $\mathrm{CO}$, carbon dioxide $\mathrm{CO}_{2}$ and unburned hydrocarbon $\mathrm{HC}$ are examined during running of the engine with and without the presence of magnetic coils. The engine performance parameters (brake power, brake specific fuel consumption and brake thermal efficiency) are investigated too .Two magnetic coils with different intensities (1000 and 2000 Gauss) were used. The magnetic coil is placed on the line of fuel supply before the carburetor. All tests were conducted at a wide open throttle (WOT), compression ratio 10:1, speed of $2000 \mathrm{rpm}$ and ignition timing (between $5^{0}$ and $30^{\circ}$ BTDC ) . Results show a significant reduction in exhaust gas emissions when applying the magnetic field. A maximum reduction of $68.8 \%$ of $\mathrm{CO}, 15 \%$ of $\mathrm{CO}_{2}$ and 42.5\% of $\mathrm{HC}$ are observed when using 2000 Gauss magnetic coil. Moreover, it was noticed that all engine-affecting parameters were improved. Running the engine with 2000 Gauss and 10 vol.\% ethanol-gasoline blends shows better results ( concerning pollution emissions and brake thermal power ) than 1000 Gauss magnetic coil .

$$
\begin{aligned}
& \text { تقليل انبعاث الملوثات الغازية من محركات الاحتراق الداخلي التي تعمل بمزيج } \\
& \text { الايثانول - الكازولين من الممغنط } \\
& \text { رعد علي خليل } \\
& \text { جامعة الموصل ـ كلية الهندسة ـ ق قعم الهندسة الميكانيكية ـ الموصل . }
\end{aligned}
$$

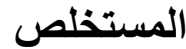

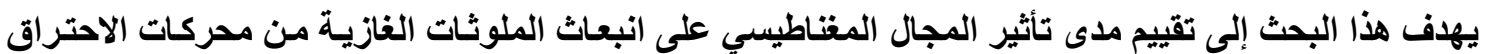

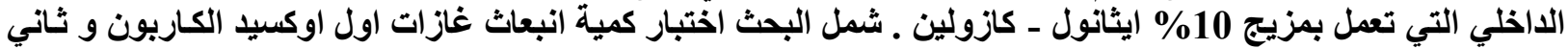

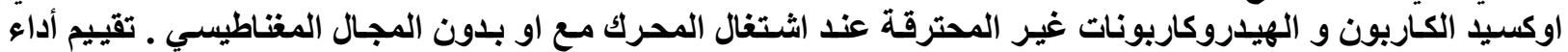

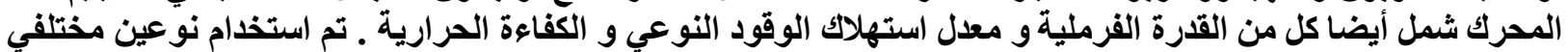

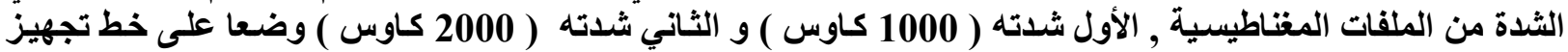

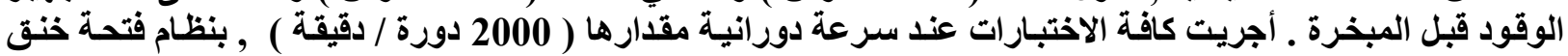

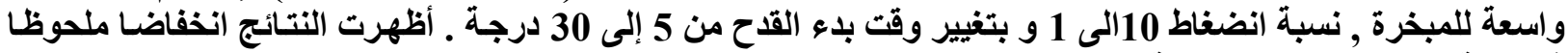

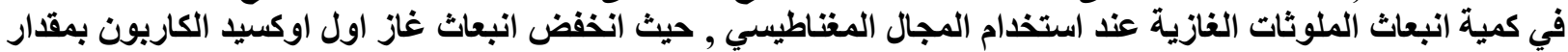

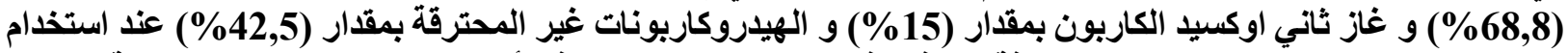

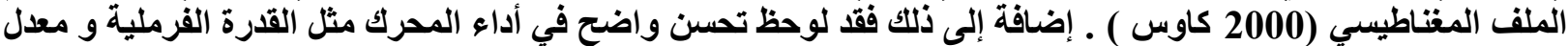

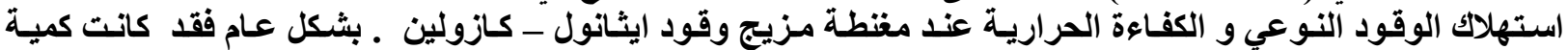
الملوثات الغازية المنبعثةً عند استخذام الملف المغناطيسي (2000 كاوس) اقلّ منها عند استخذام الملف ( 1000 كاوس ) .
\end{abstract}

Received: 8 - 2 - 2011

Accepted: 14 - 8 - 2011 


\section{Introduction:}

Engines manufacturers worldwide concentrated their efforts to develop spark ignition engines with high thermal efficiency and low specific fuel consumption without violating the accepted level of emissions regulations. For the reduction of pollutant emissions , researchers have focused their interest on the use of bio-fuels to limit and decrease the greenhouse gases $\left(\mathrm{CO}_{2}\right)$. The best candidate bio-fuels are alcohols, which can be blended with gasoline. Ethanol will probably be the most important alternative fuel since it has a higher octane number than gasoline. Adding ethanol to gasoline will increase the octane number and thus improve the performance of the vehicle. Today ethanol-gasoline blends with different percentages are commonly used in various countries around the world, especially Australia ( $10 \%$ ), Brazil ( up to 25\% ), Canada (10\%), Sweden ( 5\%) and USA ( up to 10\% ). There still debate about whether, how and what extent ethanol in gasoline may affect the materials in the vehicle, cause excessive wear of parts in the fuel system, and engine. However, in the USA, car manufacturers have agreed that the use of gasoline with up to $10 \%$ ethanol will not affect the warranties of their vehicles [1].

M. A. Cevez , F. Yuksel [2] ,investigated experimentally the effect of ethanol-unleaded gasoline blends on cyclic variability and emissions in an SI engine . Results showed that using ethanol-unleaded gasoline blends as a fuel decrease $\mathrm{CO}$ and $\mathrm{HC}$ emission concentration and the $10 \mathrm{vol} \%$ ethanol in fuel blend give the best result .

Abdel-Rahman and Osman [3] , found that the maximum improvement in engine indicated power occurred with a $10 \%$ ethanol blend when adapting variable compression ratio .

Hassan S. Hamoody [4], in his MSc thesis showed that the best performance of the SI engine with little emission of pollutants was during operating the engine with compression ratio $10: 1$, ignition timing ( $20^{\circ}$ BTDC ), equivalence ratio ( $\left.\Phi=1\right)$ and engine speed at ( $\left.2000 \mathrm{rpm}\right)$ when using 10 vol.\% ethanol-gasoline blends .

Janezak and Krensel [5], conducted an experimental test for treating gasoline with magnetic field for more efficient combustion and pollution. Their invention relates to permanent magnet units mountable as retrofit adaptors outside a fuel line without disconnection or modification of the fuel or ignition system .

Charles H. Sanderson [6] , in his invention , showed a method and apparatus for treating liquid fuel in an internal combustion engines by passing it through a magnetic field prior to mixing it with air in the carburetor or the fuel injector.

Al-Dossary, Rashid [7] , in his Msc thesis, conducted an experimental research to study the effect of magnetic field on internal combustion engine with unleaded gasoline .Al-Dossary found that the effect of magnetic field on $\mathrm{CO}$ was the most significant at most engine's loads and speeds .

Govendasamy and Dhandapani [8], investigate experimentally the effect of using magnetic field on reduction of exhaust emissions in Bio-diesel engine with exhaust gas recirculation (EGR). They found that with the presence of the magnetic field, a satisfactory reduction in $\mathrm{CO}$ and $\mathrm{HC}$ emissions with an increase of 5\% in the brake thermal efficiency are obtained .

In the present study, $10 \%$ by volume ethanol-gasoline blends was used in a singlepiston, four - stroke, water-cooled variable compression spark ignition engine supplied with Dc-dynamometer and on-line exhaust gas analyzer. The study concentrates on the effect of magnetic field ( two magnetic coils with different intensities applied on the fuel supply line before entering the engine carburetor ) on exhaust gas emissions ( $\mathrm{CO}, \mathrm{CO}_{2} \& \mathrm{HC}$ ) and engine performance ( brake power, brake thermal efficiency and specific fuel consumption) . 


\section{Experimental work:}

Experiments were carried out on a single piston, four - stroke cycle , variable compression ratio spark ignition engine. The engine is operated at wide-open throttle (WOT) with an equivalence ratio of $\Phi=1$. The compression ratio was adjusted to be 10:1 and ignition timing was varied from $5^{0}$ to $30^{0}$ BTDC with $\left(5^{\circ}\right)$ intervals .Engine speed was set at $2000 \mathrm{rpm}$ . The engine was fueled by blends of $10 \mathrm{vol}$. \% ethanol-gasoline. The gasoline which has been used was a leaded gasoline produced by Iraqi Northern Oil Company ( Beiji refinery) . Two magnetic coils with different intensities (1000 \& 2000 Gauss) were used to treat the bio fuel before entering the carburetor of the engine.

Exhaust emissions gases $\left(\mathrm{CO}, \mathrm{CO}_{2}\right.$ and $\mathrm{HC}$ ) were measured by using an on-line digital gas analyzer during all tests, with and without the presence of magnetic coils. Engine parameters such as brake power, brake specific fuel consumption and brake thermal efficiency were studied too .Figure [1] shows a schematic arrangement of the engine test bed

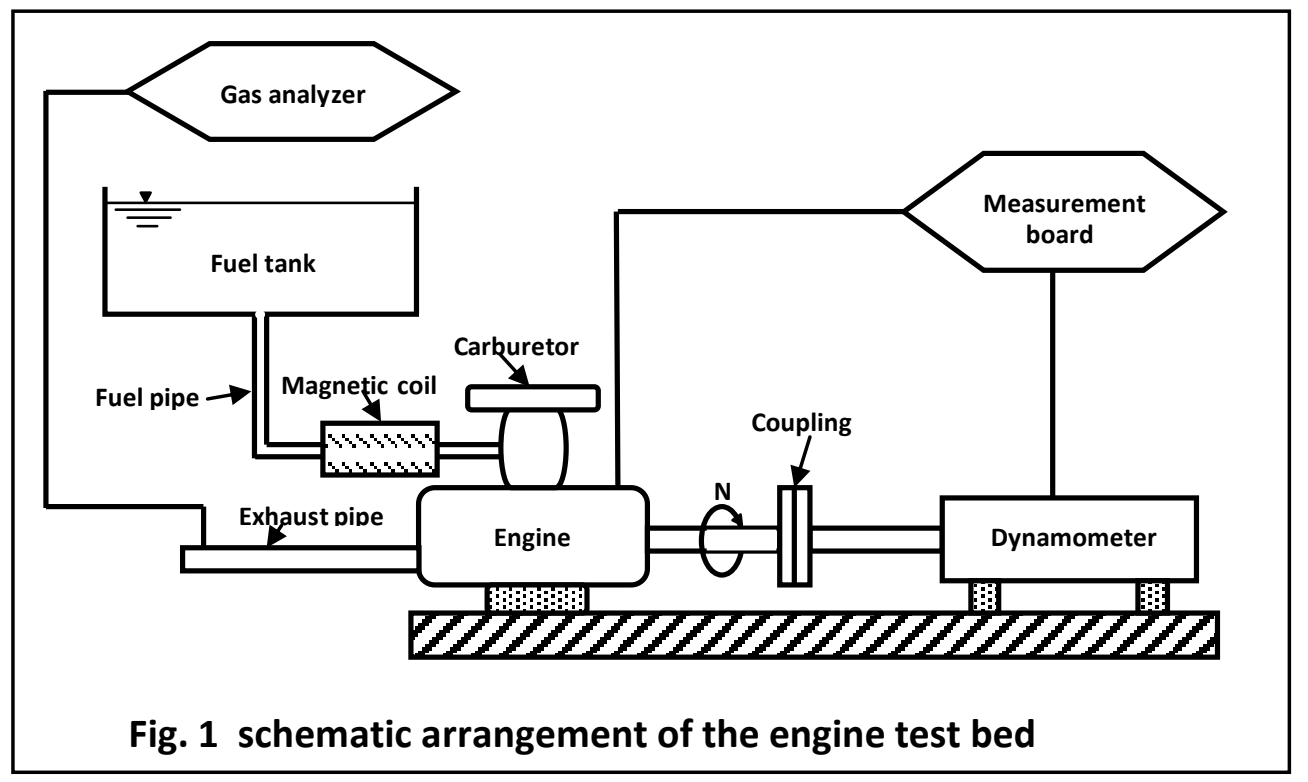

\section{Results and Discussion:}

Exhaust gas emissions and engine performance were investigated with the use of a blend of $10 \%$ vol. ethanol - gasoline ( leaded ) and magnetic coil applied to the line of fuel before entering the carburetor at engine speed of $2000 \mathrm{rpm}$, compression ratio of 10:1 and wide open throttle (WOT) . All tests were carried out either with the presence of 1000 gauss magnetic coil, 2000 gauss coil or without the magnetic effect. Figure (2) shows the variations of carbon monoxide $\mathrm{CO}$ emissions with ignition timing. A significant reduction of $68.8 \%$ in $\mathrm{CO}$ was found to be at $30^{\circ} \mathrm{BTDC}$, when using 2000 Gauss, while, the maximum reduction when using 1000 Gauss was $50 \%$ at 25 and 30 degrees BTDC. Carbon dioxide $\mathrm{CO}_{2}$ was reduced by $15 \%$ at $25^{\circ}$ BTDC and $3.7 \%$ at $15^{\circ}$ BTDC, when using the magnetic coils with intensities of 2000 Gauss and 1000 Gauss respectively as shown in figure (3). A good improvement in unburned hydrocarbons $\mathrm{HC}$ emissions were found when applying the magnetic field. Figure (4) shows that the maximum reduction in $\mathrm{HC}$ was $42.5 \%$ at $15^{\circ}$ BTDC 
with a magnetic coil of 2000 Gauss. Using a magnetic coil of 1000 Gauss showed a reduction of $12.5 \%$ at $15^{\circ} \mathrm{BTDC}$.
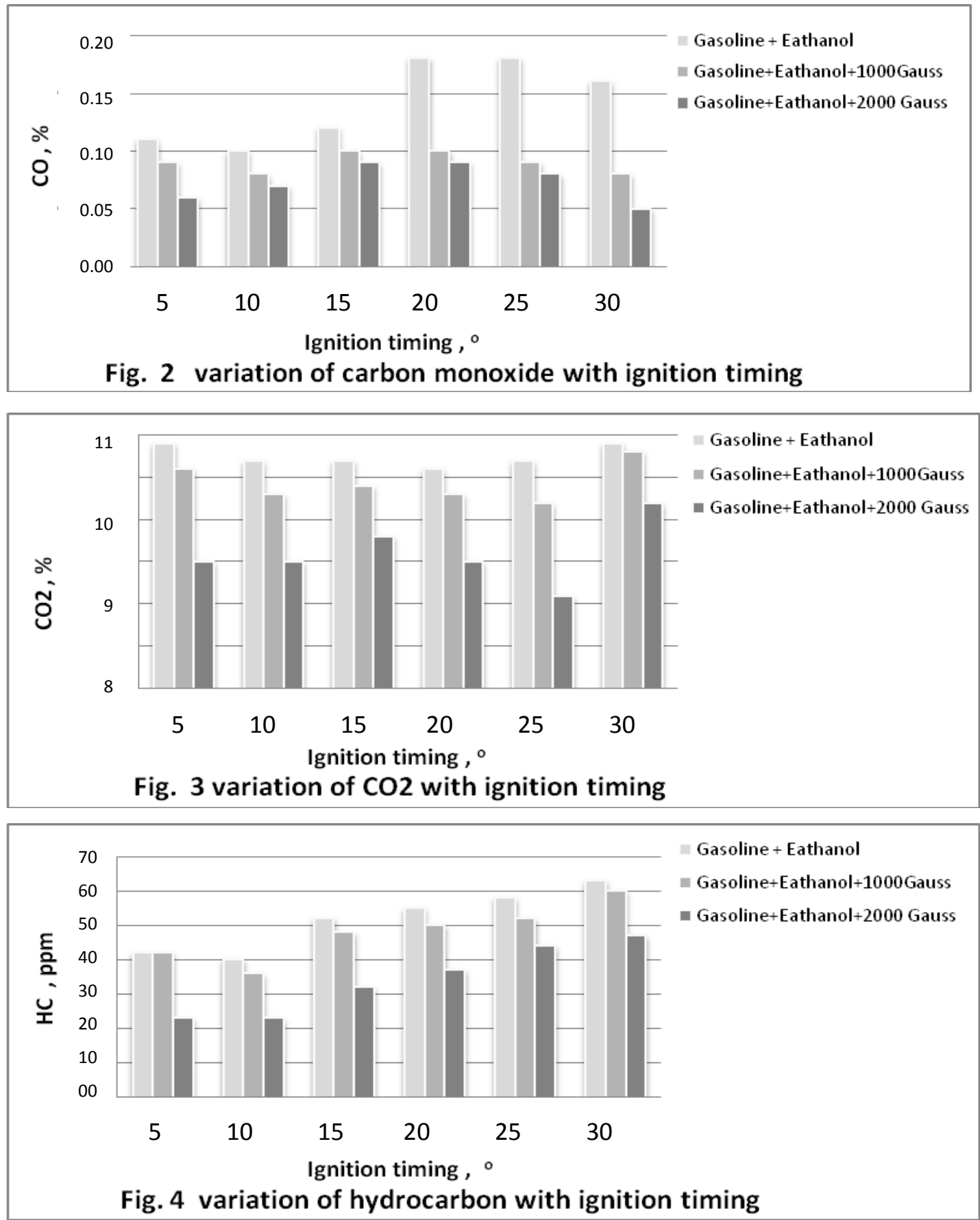

Using the magnetic field with ethanol-gasoline blends improves the engine performance parameters too. Figure (5) shows the relation between brake thermal power and engine ignition timing. Thermal power was improved by $8.6 \%$ at $20^{\circ}$ BTDC when using the 2000 Gauss coil, while implementing 1000 Gauss coil showed a $4.4 \%$ increment in thermal power at $10^{\circ}$ BTDC. It can be seen from figure (6) that the specific fuel consumption is decreased nearly by $8.6 \%$ at $20^{\circ}$ BTDC when a magnetic coil of 1000 Gauss is used ; however , this reduction was measured to be approximately by $3.2 \%$ at $20^{\circ}$ BTDC when a magnetic coil of 
2000 Gauss was used. Figure ( 7 ) showed that the thermal efficiency increased by $4.4 \%$ at $10^{\circ}$ BTDC and $3.6 \%$ at $20^{\circ}$ BTDC when applying 1000 Gauss and 2000 Gauss respectively . Exhaust gases temperature have been measured during all tests .Results show a small effect of magnetic field on exhaust temperature . Figure ( 8 ) shows the relationship between exhaust gas temperature and ignition timing for the same engine operating conditions. Results indicate that the maximum increase in exhaust gas temperature was nearly by $1.5 \%$ at $20^{\circ}$ BTDC for 1000 Gauss coil , while applying 2000 Gauss showed a maximum decrease of 2.9 $\%$ at $25^{\circ}$ BTDC.
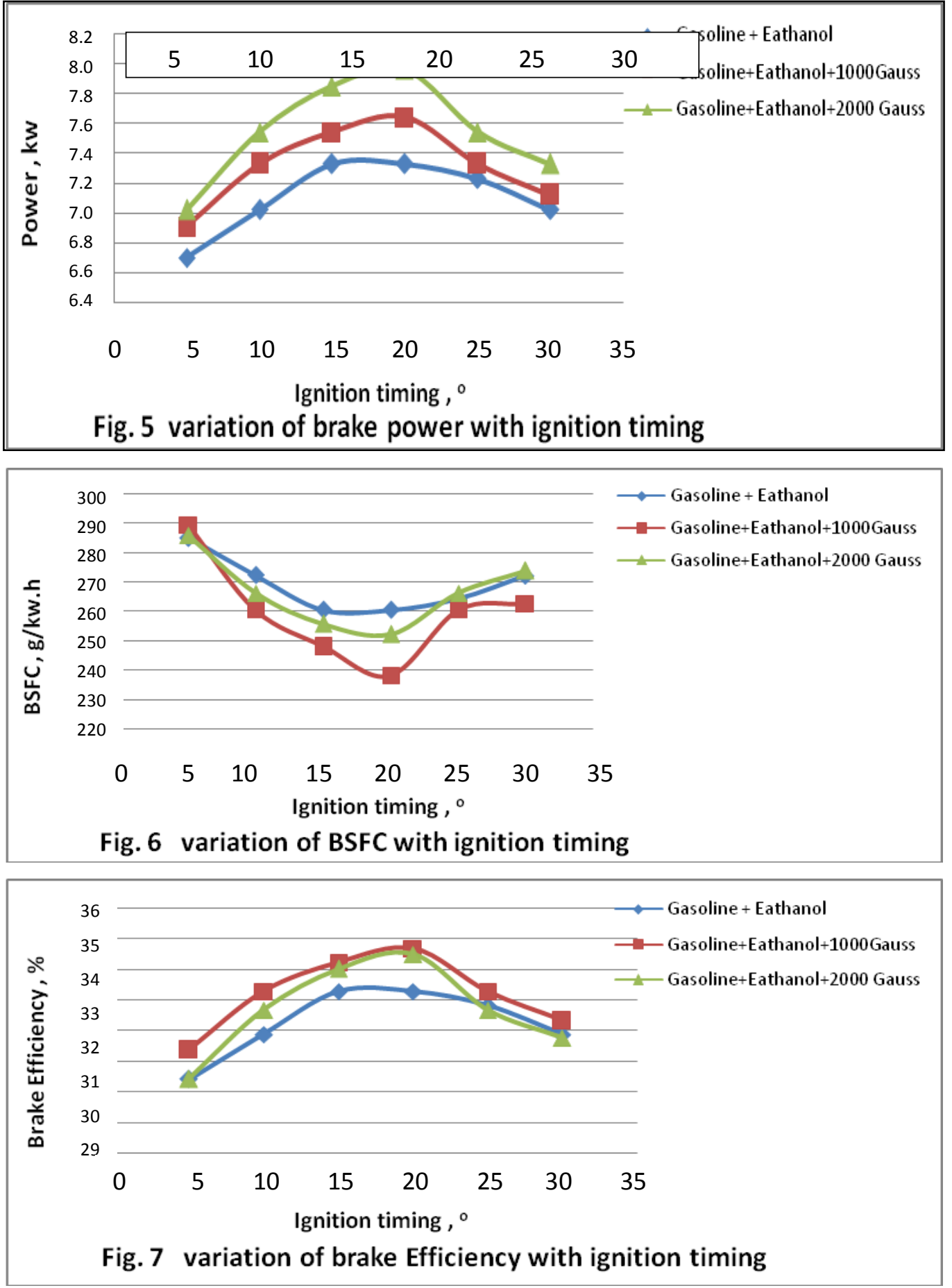


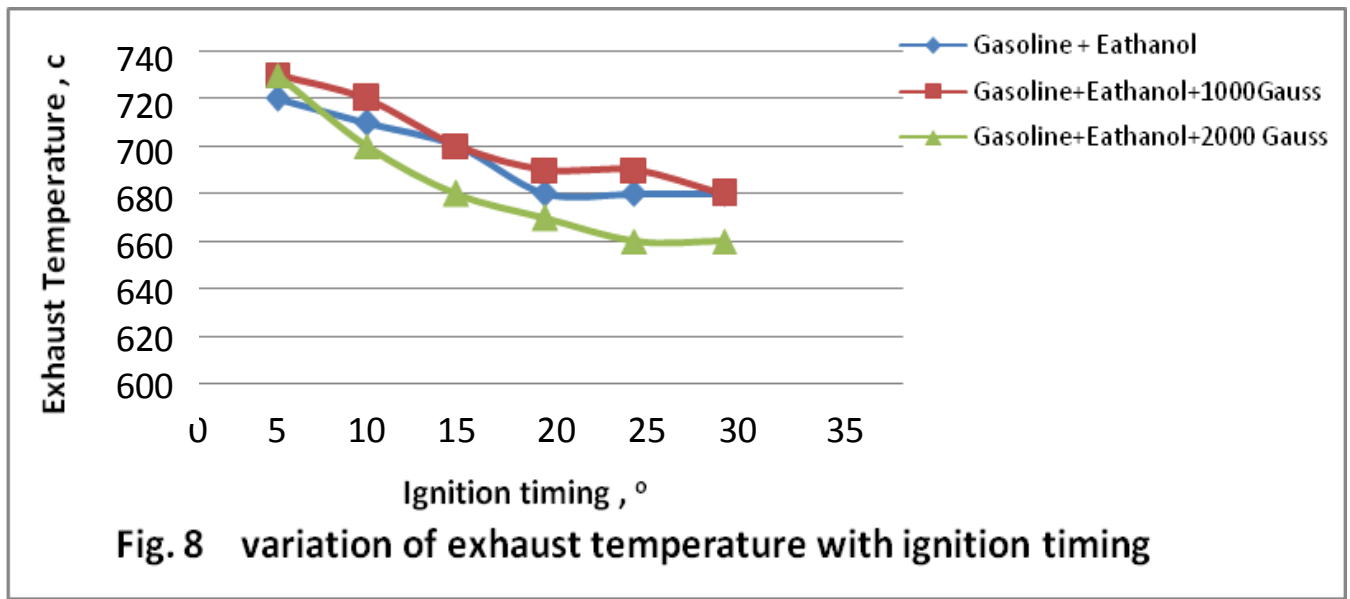

With the presence of magnetic field, the internal energy of the fuel increases which means that molecules fly apart easier, join with oxygen easier and burn more completely . The magnetic field can change the spin state of hydrogen molecules in the fuel ( converted from para-hydrogen to ortho-hydrogen ) which greatly enhances the energy of the atom and increases fuel reactivity leading to higher engine output, better fuel economy and lower amount of hydrocarbons and carbon monoxide in the exhaust .

\section{Conclusions:}

The experimental investigation conducted in this work indicated that applying a magnetic field to the fuel supply line of an internal combustion engine working with blends of $10 \%$ vol. ethanol-gasoline (leaded) is an effective way to reduce the pollutants emissions in the exhaust gases. Implementing a 2000 Gauss magnetic field leads to a reduction of $68.8 \%$ at $30^{\circ} \mathrm{BTDC}$ in carbon monoxide $\mathrm{CO}$ emission, a $15 \%$ at $25^{\circ} \mathrm{BTDC}$ reduction in $\mathrm{CO}_{2}$ and a $42.5 \%$ at $10^{\circ} \mathrm{BTDC}$ reduction in the unburned hydrocarbons $\mathrm{HC}$ combined to an increase in engine performance ( $8.6 \%$ increment in brake thermal power, $3.2 \%$ reduction in BSFC and $3.6 \%$ increment in thermal efficiency ). The exhaust gas temperature were slightly affected by the magnetic field. Running the engine with 1000, Gauss coil shows better results concerning brake thermal efficiency and brake specific fuel consumption than that with 2000 Gauss.

Finally, it can be concluded from the experimental results shown that reduced emissions of pollutants as well as improved fuel combustion, increased engine power and reduced fuel consumption for ethanol-gasoline engine as a consequence of magnetic fuel treatment are feasible .

\section{References :}

[1] Karl-Erick Egeback, Magnus Henke and Bjorn Rehnlund . Blending of ethanol in gasoline for spark ignition engines - problem inventory and evaporative measurements .AVL MTC motor test center, report no. MTC 5407, 05-2005. 
[2] M. A. Cevic and F. Yuksel . Effects of ethanol - unleaded gasoline blends on cyclic variability and emissions in an SI engines . Applied Thermal Engineering Journal ,25 (2005),pp.917-925 .

[3] A. A. Abdel-Rahman and M. M. Osman . Experimental investigation on varying the compression ratio of S.I. engine working under different ethanol-gasoline fuel blends . International Journal of Energy Research 21(1), 1997 , pp. 31-40 .

[4] Hassan S. Hamoody . Performance of the internal combustion engine working by carburetor system with adding ethanol substance to the leaded gasoline. Msc. Thesis , college of engineering, university of Mosul , 2008.

[5] A. Janezak and E. Krensel . Permanent Magnetic Power for treating fuel lines for more efficient combustion and less pollution .U.S. Pat. 5,124,045 . Sep.27, 1992 .

[6] Charles H. Sanderson . Method and apparatus for treating liquid fuel .U.S. Pat. 4,050,426 .Jun.23,1977.

[7] Al-Dossary , Rashid . The effect of magnetic field on combustion and emissions . Msc. Thesis, King Fahd university of petroleum and minerals . 2009.

[8] P. Govndasamy , S. Dhandapani . Reduction of $\mathrm{NO}_{\mathrm{x}}$ Emission in Bio Diesel Engine with Exhaust Gas Recirculation and Magnetic Fuel conditioning .International Conference on Sustainable Development , challenges and opportunities for GMs [12-14 Dec. 2007]. 